\title{
Rediscovery of Volvulella volvulaeformis (G. Seguenza, 1879) in the Italian Pliocene (Gastropoda Rhizoridae)
}

\author{
Mauro M. Brunetti
}

Calle Navas 106, 14511 Navas del Selpillar, Spain

\begin{abstract}
A fossil gastropod for the Italian Pliocene is here reported. Following bibliographical research, it is assigned to a taxon previously described and never cited: Cylichna volvulaeformis $\mathrm{G}$. Seguenza, 1880, which, according to its morphological characteristics, is assigned to the genus Volvulella Newton, 1891 (Gastropoda Rhizoridae).
\end{abstract}

KEY WORDS Gastropoda; Rhizoridae; Pliocene.

Received 12.01.2020; accepted 19.04.2020; published online 29.05.2020

\section{INTRODUCTION}

Malacological research carried in the Italian Pliocene led to the discovery of some specimens of a Rhizoridae Dell, 1952, previously described as Volvulella sp. in Brunetti \& Cresti, 2019. The subsequent examination of numerous literature led to the determination of the specimens examined as Cylichna volvulaeformis $\mathrm{G}$. Seguenza, 1880, described by the author for the Pliocene of Calabria, which is now assigned to the genus Volvulella Newton, 1891.

\section{MATERIAL AND METHODS}

The examined material was collected manually in the ground, on the surface. The following abbreviations are used in the text: $\mathrm{H}=$ total height of the shell; $\mathrm{CCM}=$ Cresti Massimo collection (Florence, Italy). For suprageneric and generic attributions, the WoRMS was followed (http://www.marinespecies.org/).

\section{RESULTS}

\section{Systematics}

Classis GASTROPODA Cuvier, 1795

Ordo CEPHALASPIDEA P. Fischer, 1883

Superfamilia BULLOIDEA Gray, 1827

Familia RHIZORIDAE Dell, 1952

Genus Volvulella Newton, 1891

type species: Bulla acuminata Bruguiere, 1792

Volvulella volvulaeformis (G. Seguenza, 1879) (Figs. 1, 2)

Cylichna volvulaeformis G. Seguenza, 1880: p. 252, tav. 16, fig. 11.

Volvulella sp. Brunetti \& Cresti, 2019: p. 116, fig. 520.

Original Diagnosis. G. Seguenza, 1880: "17. ${ }^{*}$ C. volvulaeformis $n$. sp. Tav. XVI. fig. 11. Testa ovata, antice rotundata, postice subacuta: columella subarcuata, fisuram umbilicalem constituens: os strictum, arcuatum, antice elargatum, postice gradatim attenuatum". 


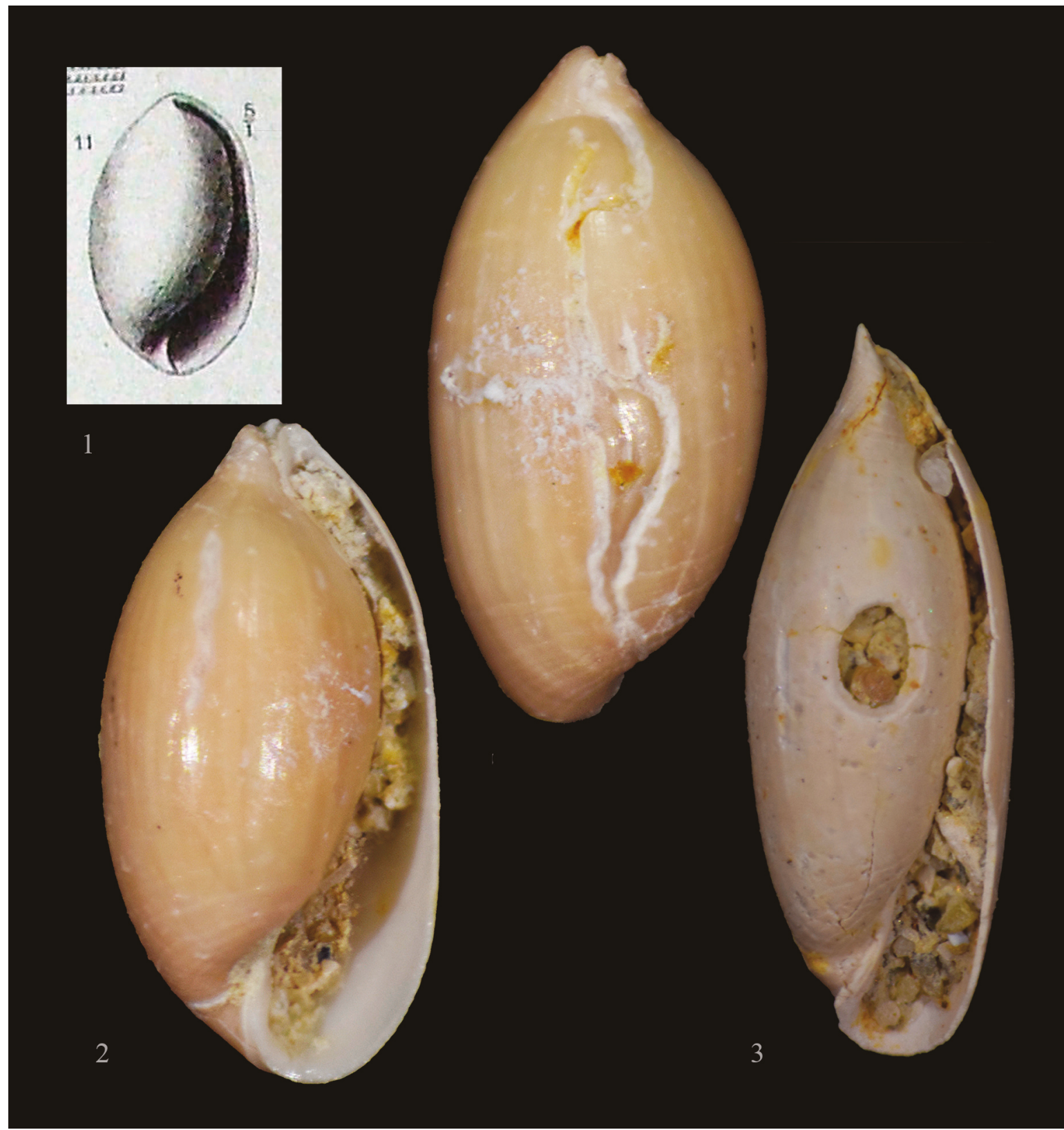

Figures 1, 2. Volvulella volvulaeformis (G. Seguenza, 1879). Fig. 1: original figure from Seguenza (1879), H $=5 \mathrm{~mm}$. Fig. 2: Orciano Pisano (Pisa), Piacenzian, $\mathrm{H}=3 \mathrm{~mm}(\mathrm{CCM})$. Figure 3. Volvulella acuminata (Bruguière, 1792) Orciano Pisano (Pisa), Piacenzian, $\mathrm{H}=4 \mathrm{~mm}(\mathrm{CCM})$.

DESCRIPTION. Shell with maximum dimensions $<5 \mathrm{~mm}$. Oval shape, with thin shell, convex sides, pointed apex. The shell is formed entirely from the last whorl. Aperture rear wide, narrows to two thirds of the whorl, with thin, sharp lip. Rounded front end, narrow navel, partially closed. Columellar callus slightly extended, there is a hint of plica inside. Sculpture composed of thin spiral grooves more evident at the ends, absent in the center of the shell.

REMARKS. I think it is interesting to propose the author's observations on this taxon. This species is very distinctive for its shape, which does not present any parting to the posterior region, and which instead protrudes and is almost acute. It appears to 
be carved from the mouth which continues to be narrower and narrower until to the extreme part. This character is found in the genus Volvula, and therefore this species is to be considered as a link between it and the Cylichna (G. Seguenza, 1879: 253).

This species is easily recognizable for the characteristic oval shape at the base with the pointed apex. The most similar species is Volvulella acuminata (Bruguière, 1792) (Fig. 3) which differs from $V$. volvulaeformis (G. Seguenza, 1879) for the shape of the narrowest shell, the thinnest and most pointed apex, the different shape of the lip. The species had recently been iconographed as Volvulella sp. by Brunetti \& Cresti (2019).

The material examined consists of 6 specimens from the Piacenziano of Orciano Pisano (Pisa). Another specimen, unfortunately destroyed, was found by the writer in the middle Pliocene of the Rio Crevalese (Piacenza). The specimen shown by G. Seguenza (1879) (Fig. 1) had been found in the locality "Astian" of Gallina (Reggio Calabria) from which most of the species established by G. Seguenza came, unfortunately destroyed due to the Messina earthquake of 1901. The locality "Astian" of Gallina includes a chronostratigraphic interval that varies from late Pliocene to the early Pleistocene (La Perna \& d'Abramo 2010). We agree with Bertolaso \& Palazzi (2000) whether or not to establish a neotype against this possibility if not in possession of topotypical material, absent in this case.

\section{ACKNOWLEDGEMENTS}

Special thanks to my friend Massimo Cresti (San Casciano V.P., Florence, Italy) for the material made available.

\section{REFERENCES}

Bertolaso L. \& Palazzi S., 2000. Note sulla raccolta Seguenza di molluschi plio-pleistocenici della provincia di Messina conservata presso il Museo di Geologia e paleontologia dell'Università di Firenze. Bollettino Malacologico, 35: 3-44.

Brunetti M.M. \& Cresti M., 2018. I fossili di Orciano Pisano, Atlante Iconografico. Edizioni Danaus, Palermo, 228 pp.

La Perna R. \& D’Abramo M., 2010. Una collezione di G. Seguenza conservata presso l'Istituto Tecnico Commerciale "O.G. Costa" di Lecce. Bollettino Malacologico, 46: 29-35.

Seguenza G., 1879. Le formazioni terziarie della provincia di Reggio (Calabria). Memorie della Reale Accademia dei Lincei, Classe di Scienze Fisiche, Matematiche e Naturalistiche, 3, 6: 1-446.

WoRMS, 2020. WoRMS, World Register Marine Species: www.marinespecies.org 
